International Journal of Social and Administrative Sciences

$\operatorname{ISSN}(e)$ : 2521-0556

DOI: $10.18488 /$ journal.136.2018.32.83.90

Vol. 3, No. 2, 83-90

(C) 2018 AESS Publications. All Rights Reserved.

URL: www.aessweb.com

check for
updates

\title{
CAPITAL STRUCTURE AND STOCK PRICES: EMPIRICAL EVIDENCE FROM LISTED BEVERAGE, FOOD AND TOBACCO COMPANIES IN SRI LANKA
}

\section{V.A.Subramaniam ${ }^{1}$ \\ (iD) S.Anandasayanan ${ }^{2+}$}

\author{
${ }^{1,2}$ Senior Lecturer Dept of Financial Management University of Jaffna Sri \\ Lanka \\ ${ }^{2}$ Tel: 0773880289 \\ 'Email:sayananatishi@yahoo.com Tel:094779596671
}

ABSTRACT

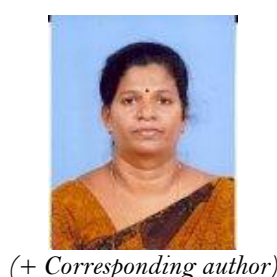

Th) Check for updates

(+ Corresponding author)

\section{Article History}

Received: 13 September 2018 Revised: 16 October 2018 Accepted: 22 November 2018 Published: 20 December 2018

\section{Keywords}

Share price

Capital structure

Debt and equity

Market efficiency

Panel least square method
The share price of a firm is affected by various factors. Determination of share price is not an easy task. The share price movement is based on the firm's fundamentals, Market efficiency, Macroeconomic Indicators and Perception of the Investors. Several studies have proven that share price of firms are explained by its capital structure. This study tests the relationship between capital structure and share prices of the listed Food and Beverage Tobacco companies in CSE for the period from 2011/2012 to 2016/2017. It analyzes the relationship between share price and capital structure by employing panel least square method approach. According to the results of the study there is a positive relationship between debt to equity and share prices . The results were statistically significant at $1 \%$ level of significance. The results indicate adding debt to overall capital positively effects on the share prices. These findings have important implications for managers or people who take decisions regarding capital structure. The changes in capital structure may have a significant impact on stock prices of the companies.

Contribution/ Originality: This study contributes to update the existing knowledge on the relationship between capital structure and stock prices particularly companies in the food, beverage and Tobacco sector in Sri Lanka. In addition this study uses residual diagnosis in order to check the model fitness.

\section{INTRODUCTION}

\subsection{Background of the Study}

Capital structure is a mixture of a various long-term equity shares and sources of funds including surpluses and reserves of an enterprise. A capital structure of an organization is the combination of its financial liabilities and its capital is usually uncertain but is a crucial resource for all firms, finance suppliers which are able to apply control over firms (Harris and Raviv, 1991). Equity and debt are the two main liabilities classes, with debt and equity proprietors acting on behalf of the two types of investors in the firm. Each of these is associated with different levels of risk, benefits, and control. The bank's ability to solve the needs of the stakeholders' is strongly linked to capital structure. In financial terms, it is a way a firm will try to finance its own assets by combining equity and debt (Velnampy and Niresh, 2012). 
A firm's capital structure is then a composition or structures of its liabilities which affects the share prices performance of any organization. The level of share price has been considered very significant specifically as an alternative for market liquidity. Investment in securities is also significant to expansion a country's economy and corporate bodies in general. If there is a developed economic environment and managers and stakeholders in the corporate level have the positive expectations about the future, they would normally want to expand. This expansion can take many ways such as increase sales, an enlarged plant, and the acquisition of more powerful and modern equipment. Therefore, the suitable circumstances are expected to result to corporate performance (Abdul, 2012). Few studies examined capital structure in emerging markets like Sri Lanka. However most of the research work carried out in developed countries and very little is known about the impact of capital structure on share price in developing economies. Thus this study intends to fill this research gap.

\subsection{Statement of the Problem}

The decision of capital structure is significant for any organization in any economy. It is usually demanding for business firms to figure out the right mixture of equity and debt. The decision is crucial because of the requirement to maximize returns to various organizational departments. According to Nimalathasan and Brabete (2010) capital structure of Sri Lankan listed companies is influenced by size, profitability and tangibility of assets. Share prices are one of the major avenues of investment which gives higher returns to investors. A number of transactions take place every movement, it is very difficult for a common man to find out where to invest as they may be cheated by fraud companies and there is every chance of losing the heard earned money. The Returns from investments in equity are subject to differ, depending upon a variety of indicators such as the performance of the market conditions and certain stock, therefore knowledge of such factors and their possible impact on share prices is must, as it will help the investors to make wise investment decisions and enable firms to enhance their market value. However such researches are very rarely carried out in Sri Lanka. Therefore the research problem could be stated as follows." To what extent the capital structure has impact on stock price of Listed beverage, food and Tobacco companies in Sri Lanka."

\subsection{The Objectives of the Study}

The following can be mentioned as the objective of this study.

To find out the impact of Capital structure on the share price of Listed food, beverage and Tobacco companies in Sri Lanka

\subsection{Significance of the Study}

The importance of this study stems from the following points:

- The investors are able to know the corporate structure adopted by the selected companies.

- This study provides evidence of whether or not the capital structure affects on the share price of Listed food, beverage and Tobacco companies in Sri Lanka

\subsection{Literature Review}

Velnampy and Niresh (2012) analyzed the relationship between capital structure \& profitability of listed banking industry in Sri Lanka. . They found that there was a negative relationship between debt to equity and return on equity. Further the results suggest that $89 \%$ of the total assets in the banking sector of Sri Lanka were represented by debt.

Nirajini and Priya (2013) have done a research on" impact of Capital structure on financial performance of the Trading companies in Sri Lanka'. They found there was a positive relationship between capital structure and financial performance and also capital structure is significantly affect on gross profit, net profit and ROCE. 
Anandasayanan et al. (2013) analyzed "The determinant of leverage of the listed companies in Sri Lanka; An empirical Study. The purpose of present study was to investigate the determinants of leverage (or capital structure) decision of Sri Lankan firms based on a panel data set over a period of five years from 2007-2011 comprising of 60 companies. This study examined the impact of five firm specific factors - firm size, firm growth rate, profitability, and asset tangibility, on the leverage decision of listed companies in Sri Lanka. The results showed that financial leverage of Sri Lankan firms is influenced by firm size, firm growth rate and profitability. This study contributed to the literature on the factors that influence financial leverage of the firm.

Sheel (1994) showed that all leverage determinants factors studied, excepting firm size, are significant to explain debt behavior variations. Gleason et al. (2000) Using data from retailers in 14 European countries, which are grouped into 4 cultural clusters, it is shown that capital structures for retailers vary by cultural clusters. This result holds in the presence of control variables. Using both financial and operational measures of performance, it is shown that capital structure influences financial performance, although not exclusively. A negative relationship between capital structure and performance suggests that agency issues may lead to use of higher than appropriate levels of debt in the capital structure, thereby producing lower performance.

\subsection{Data Collection and Sampling}

Food and Beverage Tobacco sector was chosen because it is one of the largest sectors of Sri Lanka in term of number of companies. The Sample size of the study is 18 companies randomly selected from food \& Beverage Tobacco companies listed in Colombo Stock Exchange. The research is based on secondary data. For the purpose of this study data were collected during the period from 2011 to 2017. Data analysis is done with the help of software packages Eview 10.

\subsection{Conceptualization}

After the careful study of review of literature the following conceptual model is developed by the researcher

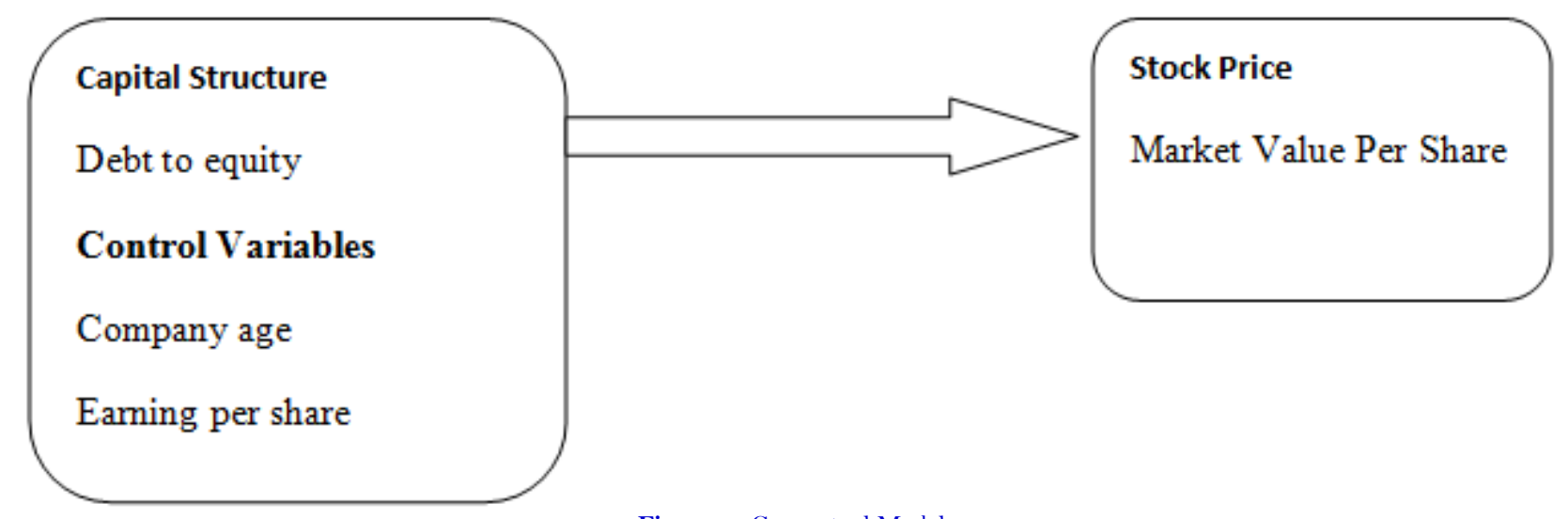

Source: Developed by Researcher

Figure-1. Conceptual Model

\subsection{Definition of Variables}

In this study capital structure ratios to be considered as independent variables and stock price is to be considered as dependent variables. To measure the capital structure of the listed Food, Beverage and Tobacco companies the following ratios are taken in this study.

Debt to Equity: The debt to equity ratio is the most important of all capital adequacy ratios The debt to equity ratio tells the shareholders as well as debt holders the relative amounts they are contributing to the capital.

\section{Debt to Equity Ratio = Total Debt $/$ Total Equity \\ Debt to Total assets Ratio}


The debt ratio is the most important ratio when it comes to gauging the capital structure and solvency an organization.

Debt Ratio $=$ Total Debt $/$ Total assets

Stock Price: The cost of purchasing a security on an exchange. A stock price is the price of a single share of a number of saleable stocks of a company.

Control Variables: In this study the following variables are to be considered as control variables.

Company Age : It is calculated that deducting the foundation year of the company from the research period.

Earning per share : Earning per share (EPS), also called net income per share, is a market prospect ratio that measures the amount of net income earned per share of stock outstanding.

\subsection{Hypotheses of This Study}

Based on theory, previous empirical studies and the research model outlined, this study has formulated the following hypotheses to examine the relationship between dependent and independent variables.

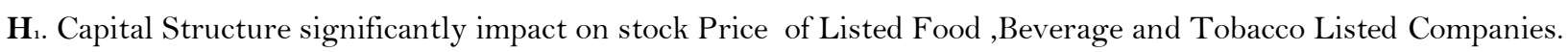

\subsection{Results and Discussion}

\subsubsection{Descriptive Statistics}

Preliminary analysis of the data was carried out for the years 2011/2012 and 2016/2017. Descriptive statistics are also useful to make general observations about the data collected. They report on the trends and patterns of data and provide the basis for comparisons between variables. General description of these variables appears on the Table 01 below.

Table-1. Descriptive Statistics

\begin{tabular}{l|l|l|l|l|l}
\hline & CL TA & COM AGE & DEEQ & EPS & MVPS \\
\hline Mean & 0.206564 & 43.18182 & 95.22688 & 26.07140 & 538.3864 \\
\hline Median & 0.292665 & 32.00000 & 56.56815 & 14.20003 & 168.2500 \\
\hline Maximum & 0.841557 & 150.0000 & 922.5467 & 204.3994 & 2700.700 \\
\hline Minimum & 0.001564 & 5.000000 & -39.31429 & -233.4164 & 2.000000 \\
\hline Std Dev & 0.217011 & 34.92407 & 131.1658 & 48.54997 & 709.5969 \\
\hline Skewness & 0.550379 & 1.782337 & 3.535786 & -0.371470 & 1.509065 \\
\hline Kurtosis & 2.360077 & 5.846095 & 20.45994 & 14.03784 & 4.067292 \\
\hline Jarque-Bera & 5.944281 & 76.29290 & 1301.141 & 448.7486 & 37.57682 \\
\hline probability & 0.051194 & 0.000000 & 0.000000 & 0.000000 & 0.000000 \\
\hline sum & 26.97766 & 3800.000 & 8441.566 & 2294.283 & 47378.00 \\
\hline Sumsq. dev & 4.097168 & 106113.1 & 1496768 & 205067.7 & 438069.15 \\
\hline Observations & 108 & 108 & 108 & 108 & 108 \\
\hline (Source: Annual Reports of Selected Companies) & & & &
\end{tabular}

The results showed that Current liability to total asset had a mean of 0.306564 with a minimum of 0.001564 , a maximum of 0.841557 , skewness .550379 and kurtosis of 2.360077 Comparatively, Company age had a mean of 43.18182 , minimum of 5 , maximum of 150 , skewness of 1.782337 and kurtosis of 5.846095 .

The mean value of Debt to Total Assets for the 88 observations of the study is $2.487448 \%$ with a standard deviation of $8.445785 \%$. Lower mean value of Debt to total assets ratio represents firm has utilized few sources of long term loans to financing its total assets. . The mean value for EPS is $26.07140 \%$ which indicates that most companies were profitable (though some of them were suffering some losses as indicated by the minimum value of 233.4164\%). Similarly, the mean value for Debt to equity is found to be, as shown in the Table95.92688\% which indicates, also, that most of the surveyed companies have higher gearing ratios. Negative and positive values of skewness mean that the results, to a certain extent, are not normally distributed. 


\subsubsection{Regression Analysis}

To find out the impact of capital structure on stock price of listed food, beverage and Tobacco companies , Ordinary least square regression model was carried out and the Table 2 presents the Results of the regression. Here the stock prices were considered as dependent variable and the debt to equity ratio was considered as independent variable.

Table-2. Results of Regression

Dependent Variable: MVPS

Method: Least Squares

Sample: 1108

Included observations: 108

\begin{tabular}{c|c|c|c|c}
\hline \multicolumn{1}{c|}{ Variable } & Coefficient & Std. Error & t-Statistic & Prob. \\
\hline C & 71.04100 & 99.44532 & 0.714373 & 0.4770 \\
\hline Debt to Equity & 2.537622 & 0.442245 & 5.738051 & 0.0000 \\
\hline Com_age & -1.363560 & 1.585565 & -0.859984 & 0.3922 \\
\hline EPS & 10.84714 & 1.217113 & 8.912191 & 0.0000 \\
\hline R-squared & 0.511629 & \multicolumn{2}{|c}{ Mean dependent var } & 538.3864 \\
\hline Adjusted R-squared & 0.414987 & \multicolumn{2}{|c}{ S.D. dependent var } & 709.5969 \\
\hline S.E. of regression & 504.6691 & Akaike info criterion & 15.33007 \\
\hline Sum squared resid & 21394036 & \multicolumn{2}{|c}{ Schwarz criterion } & 15.44268 \\
\hline Log likelihood & 29.33344 & \multicolumn{2}{|c}{ Hannan-Quinn criter. } & 1.238572 \\
\hline Durbin-Watson stat & 0.00000 & Durbin-Watson stat &
\end{tabular}

Source: Annual report of the selected companies

Table 2, shows the coefficient of Debt to Equity of -2.537622 is statistically significant at 1\% level with p-value of 0.000. It also shows the coefficient of EPS of 10.84714 is statistically significant at $1 \%$ level with p-value of 0.000 . Therefore, the first hypothesis( $\mathrm{H}_{1}$ ) is supported that capital structure significantly impact on Stock prices . In this study to measure the capital structure, debt to equity ratio was used. That means if the Debt to equity increases , market price of the stock also will increase. Usage of debt saves the tax yield on interest payment. This will improve the Share price of the stock. This result is consistent with Nimalathasan and Brabete (2010) who found positive relationship between Debt to Equity and profitability. Durbin-Watson Statistic is used to test the presence of autocorrelation in the residuals (prediction errors) from a regression analysis. The Durbin-Watson statistic of 1.238572, as revealed by the Table shows an absence of autocorrelation. It implies neither underestimation nor overestimation of the level of statistical significance. The use of an adjusted $\mathrm{R}^{2}$ is an attempt to take account of the phenomenon of the $\mathrm{R}^{2}$ automatically and spuriously increasing when extra explanatory variables are added to the model. The adjusted R-squared of 0.511629 means that variations in the independent variables can explain the variations in the dependent variables by $51.1629 \%$. Accordingly, elicited conclusions can be considered as credibly supported by the data.

\subsubsection{Multicolinearity}

VIF test was used to test multicolonearity among independent variables and it was found that VIF Values are less than 10 which means that there are no serious multicolonearity. 
Table-3. Variable Inflation factor

\begin{tabular}{c|c|c}
\hline & Coefficient & Centered \\
\hline Variable & Variance & VIF \\
\hline C & 9880.371 & NA \\
\hline DEEQ & 0.195580 & 1.149402 \\
\hline EPS & 1.481364 & 1.192739 \\
\hline COM AGE & 2.514015 & 1.047426 \\
\hline
\end{tabular}

\subsubsection{Residual Diagnosis Test}

Residual analysis provides the user various descriptive statistics and misspesification tests. Johansen suggests using residuals from the unrestricted model to decide whether the model is acceptable or not. Visual inspection of the correlograms gives quick overview whether there is left significant correlation in the residuals.

\section{Serial Correlation- Correlogram of Residuals( $Q$ statistics)}

Ho: No serial correlation exists in residuals

H1: There exists serial correlation in residuals

Date: 11/10/18 Time:20:25

Sample: 1108

Included observations: 88

\begin{tabular}{|c|c|c|c|c|c|c|}
\hline Autocorrelation & Partial Correlation & & $A C$ & PAC & Q-Stat & Prob \\
\hline$\square$ & $\square$ & 1 & 0.279 & 0.279 & 7.0919 & 0.008 \\
\hline 101 & 1 प 1 & 2 & 0.031 & -0.051 & 7.1805 & 0.028 \\
\hline 1 & 101 & 3 & 0.059 & 0.070 & 7.5071 & 0.057 \\
\hline । $\square$ । & 口， & 4 & 0.164 & 0.141 & 10.043 & 0.040 \\
\hline 1 & 11 & 5 & 0.073 & -0.012 & 10.547 & 0.061 \\
\hline 10 & 1 미 & 6 & -0.065 & -0.087 & 10.951 & 0.090 \\
\hline 1 व & 1 1 1 & 7 & -0.090 & -0.064 & 11.737 & 0.110 \\
\hline 1 미 1 & 1 미 & 8 & -0.097 & -0.092 & 12.671 & 0.124 \\
\hline 1 미 1 & 14 & 9 & -0.093 & -0.057 & 13.535 & 0.140 \\
\hline 10 & 1 & 10 & -0.076 & -0.015 & 14.128 & 0.167 \\
\hline 1 व 1 & 1 & 11 & -0.076 & -0.023 & 14.726 & 0.195 \\
\hline 11 & 101 & 12 & -0.014 & 0.049 & 14.745 & 0.256 \\
\hline 111 & 1 & 13 & 0.001 & 0.016 & 14.745 & 0.324 \\
\hline 111 & 1 & 14 & 0.017 & 0.022 & 14.776 & 0.394 \\
\hline 111 & 1 & 15 & 0.015 & 0.002 & 14.801 & 0.466 \\
\hline I प & 1 & 16 & -0.087 & -0.132 & 15.634 & 0.479 \\
\hline । & । & 17 & -0.155 & -0.152 & 18.321 & 0.369 \\
\hline । & 1 & 18 & -0.123 & -0.091 & 20.042 & 0.330 \\
\hline I प & 1 & 19 & -0.097 & -0.077 & 21.123 & 0.330 \\
\hline ו & 1 & 20 & -0.099 & -0.031 & 22.265 & 0.326 \\
\hline ו & 1 & 21 & -0.107 & -0.008 & 23.606 & 0.313 \\
\hline । 미 & 1 & 22 & -0.088 & -0.013 & 24.543 & 0.319 \\
\hline I & 1 & 23 & -0.070 & -0.029 & 25.137 & 0.343 \\
\hline 1 । & 1 & 24 & -0.068 & -0.067 & 25.708 & 0.368 \\
\hline 111 & 11 & 25 & 0.001 & -0.010 & 25.708 & 0.423 \\
\hline I & 1 & 26 & 0.072 & 0.025 & 26.373 & 0.443 \\
\hline 11 & ים & 27 & -0.017 & -0.114 & 26.413 & 0.496 \\
\hline 101 & $1 d$ & 28 & -0.027 & -0.046 & 26.506 & 0.545 \\
\hline 101 & 11 & 29 & 0.049 & 0.024 & 26.824 & 0.581 \\
\hline & ı 口। & 30 & 0.180 & 0.140 & 31.259 & 0.403 \\
\hline ו & 101 & 31 & 0.103 & 0.047 & 32.729 & 0.382 \\
\hline 1 & 1 & 32 & -0.026 & -0.048 & 32.828 & 0.426 \\
\hline 111 & 10 & 33 & -0.008 & -0.039 & 32.838 & 0.475 \\
\hline ו & 11 & 34 & 0.088 & 0.001 & 33.979 & 0.469 \\
\hline 101 & 1 & 35 & 0.052 & -0.063 & 34.380 & 0.498 \\
\hline 11 & 11 & 36 & -0.002 & -0.022 & 34.380 & 0.546 \\
\hline
\end{tabular}

Figure-2. Correlogram of Residuals( $Q$ statistics)

Source: Annual reports of Selected Companies 
By looking at the Table, which is the correlogram for the residuals, any pattern in the ACT or PACF cannot be identified which ensure the robustness of the results. Since the p values are greater than 0.05 from lag3 up to 36 lag, null hypothesis is not rejected and it is clear that the residuals are not correlated. The Q-test indicate that there is no autocorrelation still in the residuals.

\subsubsection{Heteroskedasticity Test}

The existence of heteroscedasticity is a major concern in the application of regression analysis, including the analysis of variance, as it can invalidate statistical tests of significance that assume that the modelling errors are uncorrelated and uniform-hence that their variances do not vary with the effects being modeled.

$\mathbf{H}_{\mathbf{0}}$ : No Heteroskedasticity exists in residuals

$\mathbf{H}_{1}$ : There exists Heteroskedasticity in residuals.

Table-4. Heteroskedasticity Test

\begin{tabular}{|c|c|c|c|}
\hline \multicolumn{4}{|c|}{$\begin{array}{l}\text { Heteroskedasticity Test t Breus ch pagan-Godfrey } \\
\text { Null Hypothesis:Homoskedasticity }\end{array}$} \\
\hline F- Statistics & 0.277063 & $\operatorname{Prob}(3.103)$ & 0.8418 \\
\hline Obs*R-Squared & 0.862237 & Prob Chi-Square(3) & 0.8345 \\
\hline ScaledExplainedSS & 1.372029 & Prob Chi-Square(3) & 0.7121 \\
\hline
\end{tabular}

The $\mathrm{H}_{0}$, there is a homodcedasticity is tested and the results shows in Table 4. $\mathrm{P}$ value of $\mathrm{F}$ statistics 0.8418 greater than $5 \%$ significance level means that there can reject the alternative hypotheses and accept the null hypotheses. Hence there is no heteroskedasticity in residuals.

\section{CONCLUSION}

This study has empirically investigated the impact of capital structure on the share price of 18 listed food, Beverage and Tobacco companies listed in the CSE. From the study it was concluded that borrowing money increases the debt Equity ratio thus affect the performance of the share price, increasing the debt ratio may reduce a firm's cost of capital, Minimizing the cost of capital maximizes the debt ratio which positively affects the share price performance, more over debt ratios leads to optimistic management expectations and probable future cash flows. This is supported by the theory of pecking order proposed by Myers and Majluf (1984). The theory states that firms favor internal finance sources; they employ their target dividend payout ratios to their investment opportunities although payout ratios and dividends are gradually familiar to shifts in the degree of important investment opportunities. In addition, Myers and Majluf (1984) stated that in the event that external finance is required, firms are mainly possible to offer safe security first that is to say they begin with debt then possibly convertible debt then equity comes as last resort. Myers' argument was such that businesses stick to a hierarchy of financing sources and prefer internal financing when available. Should external financing be required, debt would be preferred over equity. To add that the theory of pecking order was able to explain the negative link connecting debt ratio and profitability within an industry however; the theory did not entirely explain the capital structure differences between industries. This finding comports with the results of Harris and Raviv (1991) and Nimalathasan and Brabete (2010).

Funding: This study received no specific financial support.

Competing Interests: The authors declare that they have no competing interests.

Contributors/Acknowledgement: Both authors contributed equally to the conception and design of the study. 


\section{REFERENCES}

Abdul, G., 2012. The relationship of capital structure decisions with firm performance: A study of the engineering sector of Pakistan. International Journal of Accounting and Financial Reporting, 2(1): 2162-3082.

Anandasayanan, S., V.A. Subramaniam, A. Sireeranhan and M. Raveeswaran, 2013. The determinant of leverage of the listed companies in Sri-Lanka; an empirical study. International Journal of Research in Commerce \& Management, 03(06).

Gleason, K.C., L.K. Mathur and I. Mathur, 2000. The interrelationship between culture, capital structure, and performance: Evidence from European retailers. Journal of Business Research, 50(2): 185-191. Available at: https://doi.org/10.1016/s0148-2963(99)00031-4.

Harris, M. and A. Raviv, 1991. The theory of capital structure. The Journal of Finance, 46(1): 297-355.

Myers, S.C. and N.S. Majluf, 1984. Corporate financing and investment decisions when firms have information that investors do not have. Journal of Financial Economics, 13(2): 187-221. Available at: https://doi.org/10.1016/0304-405x(84)900230.

Nimalathasan, B. and V. Brabete, 2010. Capital structure and its impact on profitability: A study of listed manufacturing companies listed in Sri Lanka. Young Economists Journal / Young Economists Magazine, 1(15, 7): 55-67.

Nirajini, A. and K. Priya, 2013. Impact of capital structure on financial performance of the listed trading companies in Sri Lanka. International Journal of Scientific and Research Publications, 3(5): 1-9.

Sheel, A., 1994. Determinants of capital structure choice and empirics on leverage behavior: A comparative analysis of hotel and manufacturing firms. Hospitality Research Journal, 17(3): 1-16. Available at: https://doi.org/10.1177/109634809401700302.

Velnampy, T. and J.A. Niresh, 2012. The relationship between capital structure and profitability. Global Journal of Management and Business Research, 12(13).

Views and opinions expressed in this article are the views and opinions of the author(s), International Journal of Social and Administrative Sciences shall not be responsible or answerable for any loss, damage or liability etc. caused in relation to/arising out of the use of the content. 